\title{
The Life Esidimeni tragedy: The courts are also to blame
}

Most discussions on the Life Esidimeni tragedy focus on the cruel approach of the Gauteng Department of Health (GDoH), while little is said about other major role players that could have averted the tragedy. By dismissing an application in March 2016 to prevent these patients from being discharged from Life Esidimeni, the Courts assisted the GDoH in its deed. This editorial describes international, regional and South African Human Rights Law, the attempts to avert the tragedy through the courts, and the need for those responsible to be held accountable for this injustice.

\section{Human rights law: Background and context}

The World Health Organization defines health as a 'state of complete physical, mental and social well-being and not merely the absence of disease or infirmity. ${ }^{[1]}$ The Office of the United Nations High Commissioner for Human Rights frames the right to health as '...a fundamental part of our human rights and of our understanding of a life in dignity. The right to the enjoyment of the highest attainable standard of physical and mental health .... ${ }^{[2]}$

The right to health is a fundamental human right crucial for the realisation and enjoyment of other human rights and is therefore an all-inclusive human right interconnecting with others, such as the rights to life and dignity. Human rights are the basis for human dignity, justice, tolerance and mutual respect. People with mental health problems are often exposed to human rights violations, such as inadequate and harmful care and treatment, severe discrimination and inadequate housing and nutrition. ${ }^{[3]}$ These violations are often motivated by misconceptions associated with mental illnesses, which can reduce an individual's access to adequate healthcare. ${ }^{[3]}$ Poor patient care management, misinterpretation of mental health policies, cost reduction actions and lack of care and compassion, which were all evident in the Life Esidimeni tragedy, can also violate human rights.

Mental health and human rights are therefore inseparable. Human rights instruments are important for mental health, as they provide security and protection from harm for mentally ill persons, ${ }^{[4]}$ and also enable them to live a meaningful life. International and regional human rights instruments are significant as they are the only source of law that legitimises international scrutiny of mental health policies and practices within a sovereign country and also because they provide fundamental protections that cannot be taken away by the ordinary political process. ${ }^{[4]}$

Among these legal instruments is the International Bill of Rights, consisting of the United Nations Declaration of Human Rights (1948) (UDHR), ${ }^{[5]}$ the International Covenant on Civil and Political Rights (1966) ${ }^{[6]}$ and the International Covenant on Economic, Social and Cultural Rights (1976). ${ }^{[7]}$ Although the UDHR is not legally binding, it establishes a set of human rights applicable to all nations. Other legal instruments include the Convention on the Rights of Persons with Disabilities (2006), ${ }^{[8]}$ the Convention Against Torture and Other Cruel, Inhuman or Degrading Treatment or Punishment (1984), ${ }^{[9]}$ and the Convention on the Elimination of All Forms of Discrimination Against Women (1979). ${ }^{[10]}$ Regional human rights instruments include the African Charter on Human and Peoples' Rights (1981). ${ }^{[1]}$ These human rights legal instruments affirm that every human being has a right to health, life and dignity, including the right not to be treated in a cruel, inhuman or degrading manner or by discrimination, as were the Life Esidimeni tragedy victims.
South Africa (SA)'s Constitution ${ }^{[12]}$ ensures that '... every citizen is equally protected by law', and aims to 'improve the quality of life of all citizens .... Constitutional protections are catered for, such as the right to human dignity, the right to life and the right to healthcare. These rights are realised, inter alia, through the National Health Act No. 61 of $2003{ }^{[13]}$ and the Mental Health Care Act No. 17 of 2002 (MHCA). ${ }^{[14]}$ The MHCA prohibits unfair discrimination against people with mental illness and other disabilities. It recognises that mentally ill persons 'may at times require protection ... and that there is a need to promote the provision of mental healthcare services in a manner which promotes the maximum wellbeing of users of mental healthcare services and communities in which they reside. ${ }^{[14]}$

SA's human rights protections for mentally ill persons are derived from international and regional law. ${ }^{[15]}$ Thus, having signed and/or ratified these legal instruments, SA is 'obliged to respect, protect and fulfil the rights enshrined in them. ${ }^{\text {'[12,16] }}$ The Bill of Rights of the Constitution $^{[12]}$ states that the courts and other legal bodies 'must consider international law ...' and that international law, approved by Parliament, binds SA to that law. SA is legally and morally bound to respect these human rights instruments.

Despite the international, regional and national protections, more than $140^{[17]}$ mentally ill patients under the patient care management of the GDoH died under suspicious, unlawful and unjust circumstances. ${ }^{[18]}$ The loss of life resulted from the rushed execution of the Gauteng Mental Health Marathon Project, when the GDoH 'precipitously' terminated its contract with Life Esidimeni, a facility that provided 'highly-specialised chronic psychiatric care' to mentally ill patients on behalf of the GDoH. ${ }^{[18]}$ This resulted in more than 2000 patients, some with comorbid conditions, being hurried to non-governmental organisations (NGOs) that were unable to provide basic healthcare or specialised psychiatric healthcare ${ }^{[18]}$ This was done to curb medical costs and to implement the National Mental Health Policy Framework and Strategic Plan 2013 - 2020 on deinstitutionalisation. ${ }^{[19]}$ The Health Ombudsman's report into the circumstances surrounding these deaths concluded that the human rights of the Life Esidimeni patients had been grossly violated, specifically their rights to health, life and dignity. ${ }^{[18]}$

\section{Attempts to avert the tragedy}

Many attempts were made by civil society organisations, family members and professional associations to stop the GDoH from removing patients from Life Esidimeni and placing them in institutions that could not provide them with adequate care. Ultimately they had to instigate legal action against the Department. ${ }^{[20]}$

The South African Society of Psychiatrists (SASOP) wrote to the former Gauteng Member of the Executive Council (MEC) for Health, Qedani Mahlangu, about the risks. This letter was seemly ignored and in October 2015, the former MEC terminated the contract with Life Esidimeni. ${ }^{[20]}$ In November 2015, the South African Depression and Anxiety Group, SASOP, the South African Federation for Mental Health and families of the patients pleaded in vain with the GDoH to 'slow down and follow the correct procedure to ensure proper care for the patients. ${ }^{\text {[20] }}$

In December 2015, litigation was instituted against the GDoH, which was presented with documents citing that patients needed specialised psychiatric healthcare that the NGOs could not provide. This litigation was dropped when the GDoH 'committed to a consultation and a safe process, in the best interests of the mental healthcare users. ${ }^{[20]}$ 
It promised that no patient would be moved until all parties involved agreed on the process and facilities. The Department reneged on its agreement, and announced in February 2016 that all Life Esidimeni residents would be moved from the facility.

In response to the Department's announcement, in March 2016 SECTION27 and others instigated further litigation against the GDoH to stop the transfer of 54 people to an NGO. Many were adult patients with severe mental disabilities such as schizophrenia, requiring specialised care. ${ }^{[20]}$ The GDoH argued that patients were assessed and concluded that they no longer needed professional care and, claiming that they were not obliged to consult, decided to move them. ${ }^{[20]}$ The Johannesburg High Court ruled in favour of the GDoH, which continued 'with its plans to discharge and place those who still need medical care to different facilities. ${ }^{[20]}$

\section{The failure of the courts}

The judicial system, the custodian of human rights law, has not emerged undamaged from the Life Esidimeni tragedy. Its fingerprints are on the death certificates of the more than 140 mentally ill patients, together with those of uncaring, incompetent Gauteng health officials. ${ }^{[17,21]}$ The role the judiciary played in this tragedy therefore cannot be disregarded. More than once, professional bodies, families of the Life Esidimeni residents and stakeholders approached the courts in attempts to intervene and prevent the tragedy. Despite expert witnesses and evidence presented before the courts on why the residents of Life Esidimeni should not be transferred, the judiciary ruled in favour of the GDoH. ${ }^{[21]}$

The second application to the courts in March 2016 to prevent the GDoH from discharging patients from Life Esidimeni was dismissed due to a 'lack of urgency.' ${ }^{[21]}$ Partial blame for the deaths of the more than 140 patients therefore falls on the judiciary for failing to intervene. It seems that mental health is not considered a matter of urgency in sectors of SA society, including the judiciary. The Life Esidimeni tragedy could have been averted, if only the courts had listened.

\section{Conclusion}

The unfortunate deaths of the Life Esidimeni patients is a painful reminder of our unjust society. The Constitution ${ }^{[12]}$ recognises the injustices of the past; however, it seems that we must now recognise the most recent injustices done to the most vulnerable members of our society. If the victims of the Life Esidimeni tragedy are denied justice and we fail to make those responsible accountable, ill-treatment and gross human rights violations of the mentally ill will endure. Although the Gauteng premier, David Makhura, has accepted the Health Ombudsman's report and accepts that the GDoH was negligent in its actions, ${ }^{[22]}$ it is too late, as more than 140 innocent people died in a preventable tragedy.

\section{B A Ferlito, A Dhai}

Steve Biko Centre for Bioethics, Faculty of Health Sciences, University of the Witwatersrand, Johannesburg, South Africa ames.dhai@wits.ac.za

1. World Health Organization. Constitution of WHO: Principles. 2017. http://www.who.int/about/ mission/en/ (accessed 17 July 2017)

2. United Nations Office of the High Commissioner for Human Rights (OHCHR). Fact Sheet No. 31, The Right to Health. 2008. http://www.ohchr.org/Documents/Publications/Factsheet31.pdf (accessed 17 July 2017).

3. Maiese M. Human rights violations. July 2003. http://www.beyondintractability.org/essay/humanrights-violations (accessed 1 September 2017)

4. Arena Ventura CA. International Law, Mental Health, and Human Rights. Center for Civil and Human Rights, University of Notre Dame, 2014:1-9. https://humanrights.nd.edu/assets/134859/ venturamentalhealth.pdf (accessed 1 September 2017).

5. United Nations General Assembly. Universal Declaration of Human Rights. 1948. 217 A (III). http:// 5. United Nations General Assembly. Universal Declaration of Human Rights. 1948.
www.un.org/en/udhrbook/pdf/udhr_booklet_en_web.pdf (accessed 17 July 2017).

6. Www.un.org/en/udhrbook/pdf/udhr_booklet_en_web.pdf (accessed 17 July 2017). 6. United Nations General Assembly. International Covenant on Civil and Political Rights. 16 December
1966, United Nations Treaty Series, vol. 999, p. 171. https://treaties.un.org/doc/publication/unts/ 1966, United Nations Treaty Series, vol. 999, p. 171. https://treaties.un.org/
volume\%20999/volume-999-i-14668-english.pdf (accessed 1 September 2017).

7. United Nations General Assembly. International Covenant on Economic, Social and Cultural Rights. 1966. United Nations Treaty Series, vol. 993. http://www.ohchr.org/EN/ProfessionalInterest/Pages/ CESCR.aspx (accessed 17 July 2017).

8. United Nations. Convention on the Rights of Persons with Disabilities. New York: UN, 2006. https:// www.un.org/development/desa/disabilities/convention-on-the-rights-of-persons-with-disabilities. html (accessed 17 July 2017)

9. United Nations General Assembly. Convention Against Torture and Other Cruel, Inhuman or Degrading Treatment or Punishment. 10 December 1984. United Nations Treaty Series, vol. 1465, p. 85. https://treaties.un.org/doc/Publication/UNTS/Volume\%201465/volume-1465-I-24841-English. pdf (accessed 1 September 2017).

10. United Nations General Assembly. Convention on the Elimination of All Forms of Discrimination Against Women. 18 December 1979. United Nations Treaty Series, vol. 1249, p. 13. http://www.un.org/ Against Women. 18 December 1979. United Nations Treaty Series, vol. 1249, p. 13.

11. Organization of African Unity, African Charter on Human and Peoples' Rights (Banjul Charter). 1981 CAB/LEG/67/3 rev. 5, 21 I.L.M. 58 (1982). http://www.achpr.org/files/instruments/achpr/banjul_
Crganization of African Unity, African Charter on Human and People' Rights (Banjul Charter). 1981. charter.pdf (accessed 17 July 2017).

12. South Africa. The Constitution of the Republic of South Africa. Act No. 108 of 1996. http://www.gov. za/sites/www.gov.za/files/Act108of1996s.pdf (accessed 17 July 2017).

13. South Africa. National Health Act No. 61 of 2003. http://www.gov.za/sites/www.gov.za/files/38486 r10367_gon 109.pdf (accessed 17 July 2017)

14. South Africa. Mental Health Care Act No. 17 of 2002. http://www.gov.za/stes/www.gov.za/files/a17-02. pdf (accessed 17 July 2017)

15. Dugard J. International Law: A South African Perspective. Cape Town: Juta \& Co., 1994.

16. Friedmann S. The right to health. In: Human Rights and Health. Human Rights \& Human Welfare. http://www.du.edu/korbel/hrhw/researchdigest/health/health.pdf (accessed 9 August 2017).

17. Bornman J. Life Esidimeni death toll rises to 143. News24. 10 November 2017. https://www.news24. 7. Bornman J. Life Esidimeni death toll rises to 143 . News24. 10 November 2017. https://www.news24.
com/SouthAfrica/News/life-esidimeni-death-toll-rises-to-143-20171110 (accessed 10 November 2017). 18. Makgoba MW. The Life Esidimeni disaster: The Makgoba report. http://www.politicsweb.co.za/ documents/the-life-esidimeni-disaster-the-makgoba-report_(accessed 10 July 2017).
douks.

19. National Department of Health, South Africa. National Mental Health Policy Framework and Strategic Plan 2013 - 2020. 2012. https://www.health-e.org.za/wp-content/uploads/2014/10/National-MentalHealth-Policy-Framework-and-Strategic-Plan-2013-2020.pdf (accessed 9 August 2017)

20. SECTION27. The Life Esidimeni Case Fact Sheet. http://section27.org.za/wp-content/ uploads/2017/02/Life-Esidimeni-Fact-Sheet-1.pdf (accessed 9 August 2017).

21. Mooney Ford Attorneys. Courts failed dying psychiatric patients. 6 February 2017. http://www.mfp. co.za/courts-failed-dying-psychiatric-patients// (accessed 9 August 2017)

22. Ramkissoon N, Cassim B. Life Esidimeni: The forgotten people of South Africa's healthcare system. The Daily Vox: Life and Healthcare. 6 February 2017. https://www.thedailyvox.co.za/life-esidimenithe-forgotten-people-of-south-africas-healthcare-system-nikita-ramkissoon-benazir-cassim/ (accessed 9 August 2017)

S Afr Med J 2018;108(3):155-156. DOI:10.7196/SAMJ.2018.v108i3.13011 